UDK 811.163.42’373.46:72

Izvorni znanstveni rad

Rukopis primljen 5. IX. 2019.

Prihvaćen za tisak 23. I. 2020. https://doi.org/10.31724/rihjj.46.1.2

\author{
Neda Borić \\ Arhitektonski fakultet Sveučilišta u Zagrebu \\ Fra Andrije Kačića Miošića 26, HR-10000 Zagreb \\ nboric@arhitekt.hr
}

\title{
ANALIZA TVORBENIH NAČINA U HRVATSKOME NAZIVLJU ARHITEKTURE I URBANIZMA S OSOBITIM OSVRTOM NA ZNAČENJE
}

U radu se korpusnim tipom istraživanja analiziraju tvorbeni načini u hrvatskome nazivlju arhitekture i urbanizma. Na temelju dobivenih rezultata izvedena je njihova tipologija i opisane su njihove specifičnosti. Analiza je upotpunjena osvrtom na semantičke aspekte koji ukazuju na čvrstu isprepletenost morfoloških i značenjskih aspekata u stvaranju naziva ovisno o specifičnome kognitivnom makrokontekstu, odnosno specifičnoj domeni upotrebe. Rad može koristiti budućim istraživanjima nazivljā drugih struka te poslužiti kao polazište u radu na normizaciji i usustavljivanju nazivlja arhitekture i urbanizma.

\section{Uvod}

Rad se bavi analizom tvorbenih načina $u$ hrvatskome nazivlju arhitekture $\mathrm{i}$ urbanizma u uskoj povezanosti sa značenjem. Stručni jezici i njihova nazivlja danas su u žarištu interesa interdisciplinarno usmjerenih istraživanja u okviru brojnih znanstvenih disciplina koje se bave ne samo istraživanjima jezika i njegove upotrebe već i psihološkim mehanizmima spoznaje te fenomenom znanja i informacija. Iako se u hrvatskim okvirima prepoznaju vrijedni doprinosi globalnoj istraživačkoj sceni iz jezikoslovne i/ili terminološke perspektive, nazivlja brojnih stručnih i znanstvenih područja, pa tako i arhitekture i urbanizma, još 
uvijek su nedovoljno istražena. ${ }^{1}$ Navedeno je bilo glavni poticaj za izbor te teme kojom se ujedno želi ukazati na važnost sustavnoga istraživanja načina na koje hrvatski jezik sudjeluje u stvaranju naziva. ${ }^{2} \mathrm{U}$ kontekstu suvremenih pristupa stručnome jeziku kao funkcionalnoj varijanti prirodnoga jezika (Borić 2011), u radu se polazi od sljedećih pitanja koja su ujedno okosnica i smjer u teorijskoj razradbi i praktičnome dijelu analize: Djeluju li u stvaranju naziva u arhitekturi i urbanizmu isti tvorbeni načini kao i u općemu hrvatskom jeziku, postoje li određene specifičnosti i odstupanja te u kojoj su mjeri analizirani načini u skladu s već opisanim terminološkim tvorbenim načinima u literaturi? Glavni je cilj rada stoga istražiti upravo taj tvorbeni aspekt i njegove specifičnosti u nazivlju arhitekture i urbanizma s posebnim osvrtom na značenje te izvesti tipologiju analiziranih pojavnosti. ${ }^{3}$

Iako je za potrebe analize praktičnije govoriti o pojedinim razinama lingvističkoga opisa, danas se smatra da stvarna razdioba na leksičku, sintaktičku i semantičku razinu ne postoji. U tome kontekstu i hrvatski autori govore o organizaciji leksikona hrvatskoga jezika kao o integriranoj konfiguraciji istovremeno djelujućih gramatičkih i semantičkih struktura (usp. Tafra i Košutar 2009: 88, Raffaelli 2013), pri čemu dolazi do izražaja motiviranost novostvorenih naziva, što će se pokazati i u ovoj analizi.

S obzirom na to da se rad nadovezuje na dva već provedena istraživanja tvorbenih načina u nazivljima drugih struka (Štambuk 2005, Mihaljević i Ramadanović 2006), namjera je vidjeti u kojoj će mjeri rezultati ove analize biti u skladu s njihovim rezultatima, a u kojima će se utvrditi specifičnosti i razlike. Rezultati ovoga istraživanja mogli bi korisno poslužiti u budućim istraživanjima nazivljā drugih struka. Doprinos rada u teorijskom smislu leži u potvrdi o nužnosti integriranja semantičke komponente iz suvremene kognitivno orijentirane perspektive u tvorbenoj analizi naziva, kao i u činjenici da se hrvatsko nazivlje arhitekture i urbanizma po prvi put istražuje s tvorbenoga aspekta. U praktično-

\footnotetext{
Rad se nadovezuje na istraživanja stručnoga diskursa arhitekture i urbanizma s pripadajućim nazivljem u kontrastivnoj perspektivi hrvatskoga i engleskoga jezika kojima se bavi autorica ovoga rada.

2 Uz tvorbu, ostali su načini: semantički (prijenos ili proširivanje značenja u vidu specijalizacije i/ili metaforizacije i metonimizacije), sintagmatski procesi stvaranja višerječnih naziva te hibridna kombiniranja sa stranim jezičnim elementima. Ipak, u svakoj su struci ovi načini kvantitativno i kvalitativno individualni i varijabilni.

Zbog širine teme koja bi premašila dozvoljeni obim rada ne uzimaju se u obzir strani jezični elementi koji sudjeluju u morfološkome formiranju hrvatskih naziva.
} 
me smislu analiza može poslužiti kao prikladan doprinos radu na normizaciji i usustavljivanju nazivljā, za čime postoji trajna potreba u okviru svake struke.

\section{Teorijska podloga, kontekst istraživanja i pregled literature}

Imajući u vidu činjenicu da se tvorba riječi smatra ,živom, pokretačkom snagom jezika" (Kuna 2006: 165) u procesu obogaćivanja leksičkoga fonda, ne začuđuje da je upravo tvorba riječi jedan od glavnih pokretača morfološke kreativnosti i u nazivlju. Da bismo istražili ulogu hrvatskoga jezika u tome procesu u nazivlju arhitekture i urbanizma, treba poći od referentnih izvora u literaturi o tvorbenim načinima u općemu hrvatskom jeziku, a zatim i od onih koji se bave terminološkim tvorbenim načinima. O prvome je postojeća literatura opsežna, no u njoj nailazimo na veliku raznovrsnost pristupa i neujednačenost kriterija tvorbe, tipoloških klasifikacija, pa čak i same upotrijebljene terminologije, na što upozorava Kuna (2006). Tafra i Košutar (2009) glavni uzrok tome vide u neizgrađenome sustavu razredbenih kriterija, odnosno njihovu nedovoljno jasnome hijerarhijskom ustroju. Čini se da nerijetko izostaje sintetički pogled koji bi uključivao semantički aspekt kao bitan čimbenik u nastanku riječi uz onaj gramatički, morfološki. Iako gotovo sve tipologije polaze od dvaju osnovnih tvorbenih postupaka (izvođenja i slaganja), mišljenja njihovih autora uvelike se razilaze u kriterijima njihove podrazdiobe, broju tvorbenih načina ${ }^{4}$ i načinu povezivanja tvorbenih sastavnica. Pri tome se osobito uočava nedoumica oko uvrštavanja prefiksacije u izvođenje ili slaganje te problem razlikovanja složenica $i$ sraslica. ${ }^{5}$ Što se tiče prvoga, problem proizlazi iz nedovoljno jasnih razredbenih kriterija, ali i tradicionalnoga miješanja morfološke i tvorbene razine. Naime, shvaćanje prefiksacije kao slaganja potječe iz tradicionalnoga pogleda na prefikse kao prijedloge (morfološka razina), a shvaćanje prefiksacije kao izvođenja iz pogleda na prefikse kao morfeme (tvorbena razina). ${ }^{6}$

Noviji pristupi (Horvat i Ramadanović 2012) polaze od razlikovanja dviju hijerarhijskih razina: prve (tvorbeni postupci) koja se temelji na broju tvorbenih

\footnotetext{
Primjerice od dvaju u Barić i dr. 1997 do četrnaest u Mihaljević i Ramadanović 2006.

Oba su problema relevantna za temu ovoga rada.

Više o tome v. u Mihaljević i Ramadanović 2006, Kuna 2006, Tafra i Košutar 2009, Horvat i Ramadanović
} 2012. 
osnova (izvođenje - jedna tvorbena osnova i slaganje - dvije tvorbene osnove) i druge koja se temelji na tipologiji tvorbenih načina kojima se stvaraju riječi i izražavaju različita značenja (usp. Mihaljević i Ramadanović 2006, Horvat i Ramadanović 2012). Slično tome, Tafra i Košutar (2009) rješenje vide u definiranju kriterija razredbe. Priklanjajući se također kriteriju o brojčanoj motiviranosti tvorbenih osnova, autorice i prefiksaciju i sufiksaciju (inače uvijek svrstanu u izvođenje) vide kao podtipove obaju tvorbenih postupaka i smatraju ih ravnopravnima, usporednim „rječotvornim tipovima”. Za analizu su relevantni i suvremeni kognitivnolingvistički pristupi semantici prijedloga ${ }^{7} \mathrm{~s}$ obzirom na to da su brojni nazivi u nazivlju arhitekture i urbanizma prefigirani prijedlozima. Naime, smatra se da su prvotna značenja prijedloga izražavala prostorne odnose jer je prostor jedna od temeljnih konceptualnih domena čovjekova iskustva $\mathrm{i}$ doživljaja svijeta te da su oni podloga razvitku svih ostalih značenja koja izražavaju apstraktne odnose. Budući da se arhitektura i urbanizam bave prostorom, prijedlozi koji se u toj domeni jezične upotrebe pojavljuju kao prefiksi ostvaruju se u svojoj primarnoj prototipnoj konceptualnoj domeni i svojim prototipnim značenjima. Stoga bi analiza mogla ukazati na povezanost značenja prijedloga $u$ prefiksaciji i domene upotrebe (općejezična ili stručnojezična domena).

Referentni izvori o ulozi općega hrvatskog jezika u izgradnji nazivljā pojedinih struka u hrvatskoj su stručnoj literaturi općenito malobrojni, a to osobito vrijedi za morfološku tvorbu. Štambuk (2005) posvećuje velik dio svoje analize elektroničkoga nazivlja morfološkoj tvorbi. Kereković (2012) u svojoj analizi tehničkoga nazivlja strojarske struke identificira prefiksalnu i sufiksalnu tvorbu kao izrazito plodne tvorbene načine, ali ih sustavno ne analizira. Babić (1991) terminološku tvorbu smatra tek načinom bliskim tvorbi, no Mihaljević i Ramadanović (2006: 193-194) argumentiraju neodrživost takva stava. Autorice prepoznaju svojevrstan vakuum u istraživanju terminoloških tvorbenih načina čiji uzrok vide upravo u nesređenome tvorbenom nazivlju, nejasnoćama i proturječnostima u obradbi pojedinih tvorbenih načina u općemu hrvatskom jeziku, ali i u često prisutnome stavu ,da je terminološka tvorba nešto posve odvojeno od tvorbe u općem jeziku". S njihovom se procjenom u potpunosti možemo složiti. Autorice naglašavaju važnost istraživanja i sustavne obradbe terminoloških tvorbenih načina koji bi trebali biti univerzalno primjenjivi na nazivlje svake

Za informativni uvid u tu tematiku v. Matovac 2013 i Matovac 2014. 
struke. Takva je težnja opravdana imajući u vidu važnost očuvanja ispravnih načina tvorbe naziva u hrvatskome jeziku i umanjivanja snažnoga (ponekad pretjeranoga i neopravdanoga) utjecaja stranih jezičnih elemenata, osobito anglizama, na hrvatsko nazivlje, čemu danas svjedočimo u svim znanstvenim i stručnim područjima. Stoga Mihaljević i Ramadanović najprije pristupaju razradbi prikladnijega tipološkog modela tvorbe u općem jeziku zasnivajući ga na četrnaest tvorbenih načina i zatim ga uspješno primjenjuju u svojoj analizi naziva dokazujući da se tvorba naziva ne razlikuje od tvorbe riječi u općem jeziku.

Uočljiv je i problem definiranja složenica te njihova razlikovanja od sraslica. ${ }^{8} \mathrm{Za}$ razliku od Babića (1991), Mihaljević i Ramadanović (2006) srastanje ne smatraju slaganjem. Dvije osnove povezuju se spojnicima -o-, -e-, -u- ili -i- u složenicu ${ }^{9}$ prema Babiću (1991: 41-43), pri čemu autor na temelju načina postanka razlikuje čiste složenice u kojima je drugi dio samostalna riječ od ostalih složenica kao što su složeno-sufiksalne složenice, sraslice i polusloženice, dok je glavni kriterij za složenice prema Mihaljević i Ramadanović (2006: 198) postojanje triju sastavnica, od kojih je prva punoznačna osnova, druga spojnik -o-, a treća samostalna punoznačna riječ (usp. Horvat i Ramadanović 2012: 144-145). Autorice pritom uočavaju problem njihova razlikovanja od sraslica (Mihaljević i Ramadanović 2006: 204) kod onih tvorenica čiji prvi dio završava na -o (npr. prilozi), pa -o tada nije spojnik. Prema Barić i dr. (1997: 296) tvorenica nastala slaganjem motivirana je dvjema riječima, što se dokazuje preoblikom. ${ }^{10}$ Barić (1980: 15) naglašava važnost semantičkoga aspekta složenice: složenica označava jedinstveni pojam i u njezinu su značenju udružena značenja njezinih osnovnih tvorbenih riječi (npr. vodomjer). Navedena je definicija ipak preuska i neprecizna, što će pokazati ova analiza. Time se dolazi do dvaju pojmova iz jezikoslovne teorije koji su ključni za ovu analizu i koji se pokazuju međusobno blisko povezanima - (makro)kontekst i kompozicionalnost.

Naime, nazivi u određenoj struci ne nastaju samo kao rezultat formalnih pravila tvorbe. Nazivi nastaju i u svojemu specifičnom makrokontekstu kojim se

\footnotetext{
Pitanje je relevantno za nazivlja strukā zbog velikoga broja tvorenica motiviranih dvjema tvorbenim osnovama.

9 To osporavaju Horvat i Ramadanović (2012: 142).

10 Barić i dr. upozoravaju na to da ne bi trebalo uvijek olako zaključiti da se u slučaju tvorenice s dvjema prepoznatljivim osnovama nužno radi o složenici. Naime, to može biti i izvedenica ako preobličavanje pokaže da je polazna riječ u tvorbi zapravo složenica kao jedna osnova.
} 
u suvremenim jezikoslovnim teorijama označava ukupnost kognitivnoga i jezičnoga konteksta. Radi se, dakle, o konfiguraciji znanja u kojemu stručnom ili znanstvenom području kao kognitivnoj domeni, odnosno kognitivnome okviru strukturirane mreže pojmova, a jezična realizacija u svojoj sintagmatskoj okolini njegov je integralni dio. Prema tome, nazivlje u svojoj kognitivnoj dimenziji podrazumijeva ukupnost znanja o inventaru leksičkih jedinica kao simboličkoga sustava putem kojega se znanja, spoznaje i iskustva unutar jedne specijalizirane domene znanja konceptualiziraju, strukturiraju i komuniciraju. Makrokontekst je temeljni okvir koji u danoj komunikacijskoj situaciji sudjeluje u konstruiranju značenja (eng. construal) ${ }^{11}$ naziva i conditio sine qua non njegova ispravnog razumijevanja. Svaki naziv tako svoju semantičku i terminološku vrijednost nužno zadobiva unutar svojega makrokontekta. ${ }^{12}$ Integralni dio toga makrokonteksta pojam je (djelomične) kompozicionalnosti (eng. (partial) compositionality), pri čemu Langacker (2000: 94) naglašava da semantička vrijednost cjeline složene leksičke strukture ${ }^{13}$ nije tek zbroj značenja njezinih sastavnica i naziv nije samim time predvidiv, tj. semantički transparentan, unatoč prepoznatljivoj semantičkoj motiviranosti generiranoj značenjima njegovih sastavnica. Značenje cjeline šire je (specifičnije) i za njegovu punu ispravnu interpretaciju potrebno je poznavati njezin kognitivni okvir, tj. makrokontekst.

Povezanost morfoloških i semantičkih aspekata očituje se i u ulozi makrokonteksta u generiranju tvorbene višeznačnosti sufiksa i prefiksa, što će se također pokazati u analizi.

Pregled teorijske osnove rada naznačio je određene temeljne postavke koje će poslužiti kao uporišta u analizi. U teorijsko-metodološkome smislu analiza je utemeljena primarno na uvidu u postojeće tipologije tvorbenih načina drugih nazivlja kako su ih razradile Mihaljević i Ramadanović (2006) i Štambuk (2005) kao prikladnome referentnom okviru. Analiza je upotpunjena i semantičkim aspektima koji dokazuju čvrstu povezanost značenja i gramatike te ilustriraju

Više o tome pojmu v. u Langacker 1987.

12 V. Raffaelli 2009: 185-189 o važnosti situacijskoga makrokonteksta koji u sprezi s mikrokontekstnom (sintagmatskom) razinom tvori nezaobilazan metodološki aparat istraživanja. Makrokontekst trebao bi biti integralni dio lingvističkoga opisa i u istraživanju nazivljā.

13 Pod nazivom složena leksička struktura Langacker podrazumijeva ne samo stvaranje višerječnih naziva već i tvorbene postupke, odnosno prefiksalnu i sufiksalnu tvorbu. 
kognitivnu dimenziju nazivlja koja se ogleda u njegovoj utemeljenosti u specifičnome makrokontekstu.

\section{Metodologija analize}

Analiza je provedena korpusnim tipom istraživanja. Temeljni je metodološki alat u njezinoj provedbi manji, tematski specijaliziran i homogen korpus hrvatskih tekstova o arhitekturi i urbanizmu iz nekoliko vodećíh stručnih i znanstvenih časopisa (Prostor, Čovjek i prostor, Oris i Arhitektura). Budući da su tekstovi namijenjeni isključivo stručnoj čitateljskoj publici, obilježeni su ujednačenim stilom i konvencionalno prihvaćenim te udomaćenim nazivljem. Korpus tematski obuhvaća matična područja arhitekture i urbanizma, pa se stoga opravdano može tvrditi da taj, obimom manji korpus, predstavlja reprezentativni presjek konceptualne strukture stručnih znanja s njegovom leksičko-terminološkom razinom kao konvencionalnim, reprezentativnim, tipičnim i prepoznatljivim obilježjem stručnoga diskursa arhitekture i urbanizma. Tekstovi su pažljivo odabrani i detaljno iščitani. Nazivi su izlučeni dijelom s pomoću računalnoga programa Wordsmith 7, a dijelom ručno te su provjeravani u korpusu u njihovoj sintagmatskoj i konceptualnoj okolini. Za potrebe ovoga rada izabran je ograničen broj ilustrativnih primjera. Analiza pripada kvalitativnome tipu istraživanja kao najprikladnijem za ovu vrstu analize i ciljani uvid.

\section{Rezultati}

Rezultati analize pokazuju plodonosnu ulogu hrvatskoga jezika u stvaranju naziva u nazivlju arhitekture i urbanizma morfološkom tvorbom, pri čemu se mogu razgraničiti (analogno općem jeziku) sljedeći tvorbeni načini: sufiksalni, suptrakcija, prefiksalni, prefiksalno-sufiksalni, slaganje, složeno-sufiksalni i tvorba pokrata. 


\subsection{Sufiksalna tvorba (osnova + sufiks)}

Sufiksalna je tvorba izrazito plodna u nazivlju arhitekture i urbanizma, analogno općem jeziku i drugim nazivljima. Prema tablici 1., riječ je o izvedenicama iz imeničkih, glagolskih i pridjevskih osnova, a brojni ih sufiksi semantički određuju svrstavajući ih u specifične značenjske skupine kao semantičke okvire koji odražavaju konceptualne mrežne strukture stručnih znanja unutar kognitivnoga konteksta njihove upotrebe. Taj makrokontekst može generirati i tvorbenu višeznačnost sufiksa. Primjerice, sufiksi -ač i -nik u općem jeziku označavaju vršitelja radnje, ali u struci uglavnom označavaju konstruktivne dijelove zgrade. U istu semantičku kategoriju ulazi i sufiks -(ni) ca, koji u općem jeziku označava osobu ženskoga roda, stvari ili apstraktne pojmove. No, neki sufiksi iz općega jezika tvore istu značenjsku skupinu i u jeziku struke (npr. -ište: mjesto, -nje: radnja), dok pojedini (npr. -ost) u općem jeziku i u struci označavaju stanja, no u općem jeziku to su mislene ili apstraktne imenice, a u struci svojstva kao tehničke karakteristike.

Tablica 1. Sufiksalna tvorba imeničkih tvorenica

\begin{tabular}{|c|c|c|}
\hline Imeničke tvorenice & Sufiks & Značenjska skupina \\
\hline $\begin{array}{l}\text { nosač } \\
\text { upornjak, stambenjak (profesionalni } \\
\text { žargonizam u značenju 'višestambena } \\
\text { zgrada') } \\
\text { svjetlarnik, rožnik, grednik, staklenik }\end{array}$ & $\begin{array}{l}-\mathrm{ač} \\
-\mathrm{jak} \\
-(\mathrm{n}) \mathrm{ik}\end{array}$ & $\begin{array}{l}\text { dijelovi zgrade i njezine } \\
\text { konstrukcije } \\
\text { (izvedenice od imenica, pridjeva i } \\
\text { glagola) s izuzetkom stambenjak } \\
\text { (tip zgrade) }\end{array}$ \\
\hline krovište, sjecište, uporište & -ište & mjesto \\
\hline $\begin{array}{l}\text { katnica, uglovnica, prizemnica, zidanica } \\
\text { ljetnikovac, vidikovac }\end{array}$ & $\begin{array}{l}-(\mathrm{n}) \mathrm{ica} \\
-(\mathrm{k}) \mathrm{ovac}\end{array}$ & $\begin{array}{l}\text { tipologija zgrada s obzirom na } \\
\text { poziciju, katnost, materijal i } \\
\text { funkciju } \\
\text { (izv. od imenice i pridjeva) }\end{array}$ \\
\hline $\begin{array}{l}\text { zgradarstvo, zidarstvo, graditeljstvo, } \\
\text { tesarstvo }\end{array}$ & -stvo & $\begin{array}{l}\text { građevinske djelatnosti } \\
\text { (izv. od imenica koje označavaju } \\
\text { zanimanja) }\end{array}$ \\
\hline
\end{tabular}




\begin{tabular}{|c|c|c|}
\hline $\begin{array}{l}\text { izdržljivost, izgrađenost, izgradivost, } \\
\text { nosivost, održivost, provodljivost } \\
\text { katnost, prostornost }\end{array}$ & $\begin{array}{l}\text {-ost } \\
\text {-nost }\end{array}$ & $\begin{array}{l}\text { svojstvo, stanje } \\
\text { (izv. od glagola i imenica) }\end{array}$ \\
\hline $\begin{array}{l}\text { oblikovanje, planiranje, projektiranje, } \\
\text { građenje, uređenje, opremanje, } \\
\text { iskolčenje, temeljenje, naprezanje, } \\
\text { ojačanje, opterećenje, skošenje, } \\
\text { žbukanje, podzidavanje, preoblikovanje, } \\
\text { preuređenje, preprojektiranje, } \\
\text { presvođenje, prednapinjanje, } \\
\text { prednaprezanje }\end{array}$ & -(a,e)nje & $\begin{array}{l}\text { radnje i aktivnosti u projektiranju } \\
\text { i gradnji } \\
\text { (izv. od glagola) }\end{array}$ \\
\hline $\begin{array}{l}\text { dogradnja, izgradnja, nadgradnja, } \\
\text { pregradnja, ugradnja }\end{array}$ & - nja & $\begin{array}{l}\text { rezultati radnji kojima se } \\
\text { poduzimaju intervencije } \\
\text { u prostoru i prostorno- } \\
\text { organizacijska preoblikovanja } \\
\text { zgrada i njihovih dijelova (izv. ž. } \\
\text { roda od glagolske osnove) }\end{array}$ \\
\hline zatega, prenamjena, izmjera, ispuna & $-\mathrm{a}$ & $\begin{array}{l}\text { rezultati radnji (izv. ž. roda od } \\
\text { glagola) }\end{array}$ \\
\hline
\end{tabular}

$\mathrm{S}$ obzirom na to da je temeljna retorička funkcija u arhitektonskome diskursu opisivanje, ne začuđuje da su u nazivlju arhitekture vrlo brojne pridjevske tvorenice (tablica 2.) izvedene ponajviše od imeničke osnove i sufiksa. Prema vrsti one su uglavnom opisne ili odnosne (gradivne) u funkciji opisivanja ili specificiranja značenja imenice uz koju dolaze i kojoj zahvaljuju svoj status naziva (npr. bačvasti svod). Redovito čine sastavni dio višerječnih stručnojezičnih (terminoloških) kolokacija i terminologiziranih sintagmi kao udomaćenih naziva kojima se opisuju prostorne i izgrađene strukture s obzirom na njihovu morfologiju, funkcije, sastavne dijelove, pozicije, svojstva itd..$^{14}$

\footnotetext{
${ }_{14}$ U kognitivnome smislu takve terminološke kolokacije i sintagme imaju funkciju potkategorizacije
} stručnih znanja. 
Tablica 2. Sufiksalna tvorba pridjevskih tvorenica

\begin{tabular}{|c|c|c|}
\hline Pridjevske tvorenice & Sufiks & Značenjska skupina \\
\hline $\begin{array}{l}\text { križni (svod), zabatni (zid), kutni, krovni } \\
\text { (prozor, greda), lučni (nosač), pregradnil } \\
\text { potporni (zid), } \\
\text { natječajni (rad), idejni (nacrt), prostorna } \\
\text { (organizacija); tlocrtni (razmještaj) } \\
\text { temeljna/stropna (ploča), tlačna/vlačna } \\
\text { (čvrstoća), čelična/drvena/zidana } \\
\text { (konstrukcija), krovna (terasa), } \\
\text { cementna (smjesa), žbukani/bojani/zidani (zid) } \\
\text { stambena (zgrada, jedinica), najamna (kuća), } \\
\text { pomoćna (prostorija) } \\
\text { svodno (rebro), vrtno/perivojno (uređenje) } \\
\text { parkovna (arhitektura) }\end{array}$ & -(a)ni & $\begin{array}{l}\text { dijelovi konstrukcije, zgrade } \\
\text { i djelatnosti u arhitekturi s } \\
\text { prototipnom semantičkom } \\
\text { komponentom koja se odnosi na: } \\
\text { morfološku sličnost denotata, } \\
\text { funkciju, poziciju, materijal, } \\
\text { svojstva (fizička svojstva, sile i } \\
\text { nosivost), način korištenja, itd. } \\
\text { (izv. od imenica) }\end{array}$ \\
\hline $\begin{array}{l}\text { toplinski; } \\
\text { obiteljska (kuća) }\end{array}$ & -ski & $\begin{array}{l}\text { svojstvo } \\
\text { funkcija } \\
\text { (izv. od imenica) }\end{array}$ \\
\hline $\begin{array}{l}\text { pločasta (zgrada) } \\
\text { bačvasti/rebrasti/lepezasti (svod), } \\
\text { trakasti/vrpčasti (prozor), rešetkasti (nosač) }\end{array}$ & -asti & $\begin{array}{l}\text { morfološka sličnost denotata } \\
\text { (,,kao"/,,poput”) } \\
\text { (izv. od imenica) }\end{array}$ \\
\hline $\begin{array}{l}\text { nosivi (zid/konstrukcija/stup), spušteni (strop), } \\
\text { klizna (stijena) }\end{array}$ & $\begin{array}{l}-\mathrm{iv} \\
-\mathrm{ni}\end{array}$ & $\begin{array}{l}\text { funkcija ili rezultat radnje } \\
\text { (izv. od glagola) }\end{array}$ \\
\hline
\end{tabular}

Izvan svojega sintagmatskog okruženja neke od njih pripadaju općejezičnoj domeni upotrebe (pomoćni, obiteljski, spušteni), općem znanstvenom leksiku (tzv. „subtehnički” leksik - idejni), ostalim područjima tehničkih znanosti (čelični, tlačni) ili pak užemu području srodnih tehničkih znanosti (zabatni - građevinarstvo i arhitektura).

Tablica 1. pokazuje da je i u nazivlju arhitekture i urbanizma sufiksalna tvorba vrlo plodan tvorbeni način (analogno općem jeziku i rezultatima analiza drugih nazivlja koja se spominju u ovome radu). Specifičnost je u tim primjerima velika prisutnost imeničkih tvorenica izvedenih iz prefigiranih glagola (tablica 1.) za označavanje aktivnosti i radnji u procesima projektiranja i gradnje. 
Vrijedi uočiti zanimljive razlike $\mathrm{u}$ tvorbenome, semantičkome i uporabnome smislu u odnosu na opći jezik. Primjerice, prefiksalni morfem pre-slabo je plodan u općemu hrvatskom jeziku (Babić 1991: 349), no kako primjeri u tablici 1. pokazuju, on je prilično plodan u nazivlju struke pri tvorbi prefigiranih glagola, od kojih se potom sufiksalnom tvorbom tvore nove imenice. Pokazuje se da specifični makrokontekst utječe na značenje prefiksa tako što reducira njegovu inače polisemnu strukturu iz domene općejezične upotrebe (v. Anić 1991: 524) na praktički samo dva značenja u stručnojezičnoj domeni: a) ponavljanje radnje iznova ili drugačije i b) podjelu ili reorganizaciju prostora. Čak je i značenje pod a) u struci suženo i specifičnije te označava promjene u projektu, namjeni zgrade i organizaciji prostora.

I na kraju, unatoč prepoznatliivoj motiviranosti naziva, značenje većine takvih prefigiranih struktura nije dokraja transparentno bez poznavanja njihova makrokontekstnog okvira (npr. međukatna konstrukcija, potkonstrukcija itd).

\subsection{Suptrakcija}

Analiza korpusnih primjera pokazuje postojanje visokofrekventnih i udomaćenih prefigiranih naziva kao imeničkih tvorenica izvedenih iz glagolske osnove. Marković (2013: 86) takav rječogradni postupak naziva suptrakcijom zato što se dio tvorbene osnove oduzima (odbija). Istu pojavu Babić (1991) svrstava u sufiksaciju s nultim sufiksom. Takvi su primjeri: iskop, izračun, proračun, nadozid, čija značenja upućuju na rezultate radnji; prepust (= streha) i podgled (= površina balkonske ploče gledana odozdo), čija se značenja odnose na elemente građevine, ili sklop (zgrada), kojim se označava pojam prostorne konfiguracije više zgrada.

\subsection{Prefiksalna tvorba (prefiks + osnova)}

Iako nije vrlo plodan tvorbeni način, prefiksalnom tvorbom ipak se tvore izuzetno česti, konvencionalni i udomaćeni nazivi prefigirani prijedlozima i izvedeni od imeničkih, pridjevskih i glagolskih osnova. Osnovna funkcija prefiksa u nazivlju arhitekture i urbanizma (kao i u općem jeziku) jest semantička: oni speci- 
ficiraju ili modificiraju značenje leksema uz koji su pridodani, no ne mijenjaju njihovu gramatičku kategoriju.

Tablica 3. Prefiksalna tvorba naziva

\begin{tabular}{|l|l|l|}
\hline Imeničke tvorenice & Prefiks & Značenjska skupina \\
\hline međuprostor, međukat & među- & $\begin{array}{l}\text { pozicija u prostoru - između dviju } \\
\text { površina / točki }\end{array}$ \\
\hline nadsvjetlo & nad- & $\begin{array}{l}\text { pozicija u prostoru - iznad (= prozor u } \\
\text { krovu) }\end{array}$ \\
\hline podzid, potkonstrukcija, pothodnik & pod- & $\begin{array}{l}\text { pozicija u prostoru - ispod horizontalne } \\
\text { površine }\end{array}$ \\
\hline predvrt, predsoba, predprostor & pred- & pozicija u prostoru - ispred \\
\hline
\end{tabular}

U tome tvorbenom načinu jasno dolazi do izražaja povezanost kognitivnoga makrokonteksta i profiliranja značenja u kontekstu suvremenih postavki kognitivne lingvistike. Naime, tablica 3. pokazuje da prefiksi među-, nad-, pod-i pred-svojim prototipnim značenjskim obilježjima (također navedenima u tablici) imaju funkciju specificiranja prostornih odnosa u značenjima naziva unutar kojih dolaze u konceptualnoj domeni arhitekture i urbanizma. No, dok su njihova značenja u struci isključivo povezana s fizičkim prostorom, $\mathrm{tj}$. prostornim odnosima s osobitim naglaskom na pojmovima pozicije (točke u prostoru), površine i sl., u općem jeziku oni nerijetko služe kao predodžbene sheme za izražavanje apstraktnih pojmova i odnosa. Na primjer, prefiks pod- u nazivlju arhitekture isključivo označava poziciju ispod horizontalne površine. To je značenje generičko za njegovo preneseno značenje u općem jeziku, u kojemu označava rang, status, čin podređenosti: potpukovnik, podstanar itd. Dakle, prijedlozi kao prefiksi upravo u konceptualnoj domeni arhitekture i urbanizma nalaze svoje prirodno prototipno okruženje, što je u skladu s postavkama kognitivne lingvistike koja u primarnim značenjima prijedloga vidi konceptualizaciju prostornih odnosa kao temeljne dimenzije čovjekova doživljaja svijeta. Upravo u tome kontekstu treba interpretirati i postojanje velikoga broja imeničkih tvorenica izvedenih od prefigiranih glagola sufiksalnim tvorbenim načinom u tablici 1 .

Primjeri naziva s prefiksom pred-iz tablice 1. i tablice 3. ukazuju pak na drugu zanimljivu pojavu koja se odnosi na važnu ulogu kognitivnoga makrokonteksta koji generira tvorbenu višeznačnost (polivalentnost) prefiksa unutar struke. Naime, taj prefiks sudjeluje u stvaranju više od jednoga novog značenja u struci. 
No, u sufiksalnim izvedenicama u tablici 1. taj prefiks označava način mehaničkoga djelovanja sila koje se javljaju u elementima konstrukcije (prednaprezanje, prednapinjanje), a u tablici 3. označava poziciju u fizičkome prostoru (predvrt, predsoba, predprostor).

I na kraju, primjeri u tablici 3. zgodno ilustriraju kreativan leksički i tvorbeni potencijal jednoga jezika (u ovome slučaju hrvatskoga) pri stvaranju novotvorenica (neologizama) za označavanje novih pojmova u struci.

\subsection{Prefiksalno-sufiksalna tvorba (prefiks + osnova + sufiks)}

Unatoč tome što nije vrlo plodan tvorbeni način, prefiksalno-sufiksalnom je tvorbom u nazivlju arhitekture i urbanizma stvoren manji broj visokofrekventnih naziva (v. tablicu 4.).

Tablica 4. Prefiksalno-sufiksalna tvorba

\begin{tabular}{|l|l|l|}
\hline Imeničke tvorenice & Prefiks + osnova + sufiks & $\begin{array}{l}\text { Značenjska } \\
\text { skupina }\end{array}$ \\
\hline potkrovlje, predsoblje, predvorje & pod-/pred- + krov/soba/dvor + -je & $\begin{array}{l}\text { konfiguracija } \\
\text { stambenih prostora }\end{array}$ \\
\hline podgrađe, nadgrađe, predgrađe & pod-/nad-/pred- + grad + -je & $\begin{array}{l}\text { konfiguracija } \\
\text { gradskih prostora }\end{array}$ \\
\hline dovratnik & do- + vrat + -nik & $\begin{array}{l}\text { konstruktivni } \\
\text { elementi }\end{array}$ \\
\hline Pridjevske tvorenice & Prefiks + osnova + sufiks & $\begin{array}{l}\text { Značenjska } \\
\text { skupina }\end{array}$ \\
\hline međukatna (konstrukcija) & među- + kat + -ni & $\begin{array}{l}\text { pozicija u prostoru } \\
- \text { između }\end{array}$ \\
\hline prigradsko (naselje) & pri- + grad + -ski & $\begin{array}{l}\text { pozicija u prostoru } \\
- \text { uz, do }\end{array}$ \\
\hline
\end{tabular}

\subsection{Slaganje}

Nazivi nastali slaganjem prikazani su u tablici 5. 
Tablica 5. Slaganje

\begin{tabular}{|l|l|}
\hline Složenice & Osnova + o + riječ \\
\hline $\begin{array}{l}\text { a) gradogradnja, stanogradnja, } \\
\text { vodonepropusnost, vodotoranj }\end{array}$ & im.tvorenica (imenica + -o- + imenica) \\
\hline $\begin{array}{l}\text { b) suhozid; visokogradnja, niskogradnja, } \\
\text { novogradnja }\end{array}$ & im. tvorenica (prilog na -o + imenica) \\
\hline $\begin{array}{l}\text { c) novoizgrađen, } \\
\text { niskoenergetska (zgrada) }\end{array}$ & $\begin{array}{l}\text { prid. tvorenice (prilog na -o + gl. pridjev } \\
\text { trpni ili pridjev na -ski) }\end{array}$ \\
\hline Polusloženice & \\
\hline spomen-dom, prozor-vrata, grad-spavaonica & \\
\hline
\end{tabular}

Tablica pod a) donosi mali broj visokofrekventnih imeničkih i pridjevskih čistih složenica od dviju tvorbenih osnova (samostalna riječ u drugome dijelu i spojnik -o- koji je povezuje s osnovom).

Primjeri pod b) ilustriraju već otprije opisane nedoumice u literaturi u pogledu razlikovanja složenica i sraslica. Naime, primjeri se na prvi pogled doimaju kao tipične složenice jer se radi o dvjema sastavnicama povezanima spojnikom -o-, što se u literaturi navodi kao temeljni kriterij razlikovanja složenica u odnosu na sraslice (usp. Babić 1991, Barić i dr. 1997, Štambuk 2005, Mihaljević i Ramadanović 2006, Horvat i Ramadanović 2012). Ako se prva osnova smatra pridjevom, kao što se navodi u Barić i dr. 1997, to jest tako. Međutim, moguća je interpretacija prve osnove kao priloga na -o, pa bi tada to mogle biti sraslice (koje su i tako određena vrsta složenica) ili složenice bez spojnika. Čini se da bi to bilo ispravnije ako se razmišlja o semantičkoj motiviranosti tih naziva, što ne bi trebalo gubiti iz vida. Naime, u primjeru suhozid ne radi se o zidu koji je suh, već o tehnici zidanja „na suho” (bez upotrebe vezivnoga sredstva). Slični su primjeri nazivi niskogradnja i visokogradnja. Oslanjajući se na značenja sastavnih dijelova tih složenica u općem jeziku, Barić i dr. (1997: 340), po analogiji s primjerima iz općega jezika (tvrdósan = tvrdi san), jednostavnim mehaničkim postupkom dolaze do dvaju mogućih načina preobličavanja koji ih zatim dovode do pogrešna zaključka o dvama značenjima tih složenica s prvom sastavnicom kao pridjevskom osnovom, dok druga sastavnica gradnja označava građevinu ili sam proces. Točno je da je upravo to značenje leksema gradnja, no ne i kada on kolocira s leksemima (svojim sastavnicama) novo i visoko, koji bitno mijenjaju (proširuju/specificiraju) cjelokupno značenje složenice, i to isključivo zahvaljujući svojemu kognitivnom makrokontekstu. Tako u struci niskogradnja ni 
u kojem slučaju ne znači „niska gradnja” ili „gradnja niskih zgrada” (kako to navode Barić i dr.), već „građevinska djelatnost izgradnje prometnica, mostova, tunela, vijadukata, hidrotehničkih objekata, kanala, brana i luka" (Aničić 2002: 386), pri čemu ti objekti mogu biti i visoki, dok visokogradnja ne znači ,,visoka gradnja” ili „gradnja visokih zgrada” (Barić i dr.), već „,izgradnja zgrada, stambenih, upravnih, industrijskih, sakralnih objekata, ..." (Aničić 2002: 392), pri čemu te zgrade mogu biti i niske. ${ }^{15}$ Spomenuto pak ne znači da isti semantički uzorak automatski funkcionira u primjeru novogradnja. Značenje te tvorenice upućuje na građevinu ili proces čije je bitno obilježje novo stanje, svojstvo, pa može biti složenica (pridjev koji opisuje drugu sastavnicu i spojnik -o-), ali i sraslica ako gradnju razumijemo kao radnju, aktivnost, proces (čemu je sinonim građenje), pri čemu je novo prilog. Novoizgrađen i novoprojektiran svojim značenjima označavaju prije rezultat radnje negoli stanje te bi stoga to mogle biti sraslice sastavljene od priloga (novo) i glagolskoga pridjeva trpnog (izgrađen, projektiran).

Navedeni primjeri zorno ukazuju na povezanost morfoloških i semantičkih aspekata i nezaobilaznost značenja $u$ analizi te jasno ilustriraju načelo kompozicionalnosti. Koliko god da se naziv naizgled činio transparentnim u smislu svoje semantičke motivacije, o njegovu se značenju ne može zaključivati olako kako se to čini u općem jeziku, već presudnu ulogu u tome ima njegov makrokontekst, odnosno poznavanje konceptualne strukture stručnih znanja.

Polusloženice nastaju pri slaganju dviju riječi povezanih spojnicom, no funkcija im je da označe novi pojam u struci, pa je tako i ovdje značenje cjeline specifičnije od značenja svake pojedine sastavnice, odnosno prototipna obilježja značenja svake sastavnice čine novo značenje naziva kao cjeline (grad-spavaonica). U tom je primjeru u interpretaciji također ključno poznavanje konceptualne strukturne mreže stručnih znanja kao pozadinskoga znanja.

U korpusu su pronađene i višerječne sintagme energetski-učinkovita (zgrada) i računalno-potpomognuto (projektiranje), koje se zbog prisutnosti spojnice između dvaju elemenata na prvi pogled doimaju kao polusloženice, no radi se samo o pogrešnoj uporabi spojnice.

15 Isto potvrđuje i Anić (1991: 177 i 384) navodeći promjenu značenja leksema gradnja pod utjecajem leksema nova i visoka. 


\subsection{Složeno-sufiksalna tvorba}

U nazivlju arhitekture i urbanizma osobito se važnim tvorbenim načinom pokazuje složeno-sufiksalna tvorba (tablica 6.), koja nastaje kombinacijom slaganja i sufiksacije. Korpus otkriva brojne visokofrekventne i tipične konvencionalne nazive koji slijede obrazac: dvije osnove povezane samoglasnikom -o- $\mathrm{s}$ dodatkom sufiksa. Takvim načinom nastaju ponajprije brojne imeničke, a osobito pridjevske tvorenice kojima je prva osnova pridjev, a osobito često broj (skupina b) ili prilog kao prva osnova (skupina c) ${ }^{16}$ i imenica kao druga osnova (v. tablicu 6.).

\section{Tablica 6. Složeno-sufiksalna tvorba}

\begin{tabular}{|l|l|}
\hline Imeničke tvorenice & $\begin{array}{l}\text { Osnova + -o- + osnova + } \\
\text { sufiks }\end{array}$ \\
\hline $\begin{array}{l}\text { a) pravokutnik } \\
\text { b) jednokatnica, dvokatnica, trokatnica itd. } \\
\text { c) višekatnica }\end{array}$ & $\begin{array}{l}\text { pridjev ili broj ili prilog više }+ \\
-o-+ \text { osnova + sufiks }\end{array}$ \\
$\begin{array}{l}\text { d) vjetrobran, gromobran, rukohvat, tlocrt, neboder } \\
\text { Pridjevske tvorenice }\end{array}$ & $\begin{array}{l}\text { imenica }+-o-+ \text { nulti sufiks na } \\
\text { glagolskoj osnovi }\end{array}$ \\
\hline $\begin{array}{l}\text { križnorebrasti (svod), samostojeća/samoodrživa (zgrada) } \\
\text { jednoprostoran (stan), troprostorna (kuća), } \\
\text { jednoobiteljska (kuća), } \\
\text { četverosoban/jednosoban itd. (stan),jednostrešni/ } \\
\begin{array}{l}\text { dvostrešni/četverostrešni (krov), dvozglobni (luk); } \\
\text { dvokrilna (vrata), jednobrodna/trobrodna (crkva), } \\
\text { jednokrako (stubište) }\end{array}\end{array}$ & broj + -o- + osnova + sufiks \\
\hline $\begin{array}{l}\text { slobodnostojeća (kuća) } \\
\text { višestambena (zgrada), višeobiteljska (kuća), } \\
\text { višerazinsko (parkiranje); višenamjenska (zgrada) }\end{array}$ & prilog + -o- + osnova + sufiks \\
\hline
\end{tabular}

Kod imeničkih složenica česte su imenice kao prva osnova i nulti sufiks na glagolskoj osnovi (skupina d). ${ }^{17}$ Inače, tim tvorbenim načinom u nazivlju arhitektu-

\footnotetext{
16 Ovaj rezultat sukladan je rezultatu za elektroničko nazivlje. V. Štambuk 2005: 118 .

17 Ovaj rezultat sukladan je postavki iz literature o čestim složenicama s nultim sufiksom koje nastaju ovim tvorbenim načinom. V. Babić 1991: 43.
} 
re najčešće nastaju tipično prepoznatljive imeničke i pridjevske tvorenice s brojem kao prvom osnovom. Kod pridjevskih složenica kojima prvi dio složenice završava na -o (slobodnostojeća) čini se da bi prvu osnovu trebalo interpretirati kao prilog, a ne pridjev. Moguće ih je stoga interpretirati i kao sraslice.

\subsection{Tvorba pokrata}

Za razliku od strojarskoga tehničkog nazivlja (Kereković 2012), tvorba pokrata u nazivlju arhitekture i urbanizma nije osobito česta pojava. No, zanimljiva je činjenica da je najveći broj pokrata nastao skraćivanjem hrvatskih naziva, a ne preuzimanjem stranih naziva, što je inače čest slučaj. Hrvatski jezik sudjeluje u tvorbi pokrata uglavnom u području urbanizma, a znatno manje u arhitekturi. Česta je pokrata u arhitekturi neobičan hibridni akronim POS (društveno poticana stanogradnja). Naime, sama pokrata kombinacija je dviju riječi iz naziva od kojih prva (poticana) sudjeluje u pokrati s dvama početnim slovima i stanogradnja s jednim početnim slovom, a ne sadržava riječ društveno, koja je ipak sastavni dio naziva u usmenoj ili pisanoj komunikaciji. U nazivlju urbanizma konvencionalni su nazivi nerijetko ostvareni kao akronimi: GUP (generalni urbanistički plan), PUP (provedbeni urbanistički plan), NKP (neto korisna površina), BRP (bruto razvijena površina), DPU (detaljni plan uređenja), PPUO/G (prostorni plan uređenja općine/grada), UPU (urbanistički plan uređenja), PPŽ (prostorni plan županije).

\section{Zaključak}

Provedena analiza potvrdila je polaznu hipotezu da u stvaranju hrvatskih naziva u nazivlju arhitekture i urbanizma djeluju isti tvorbeni načini kao i u općem jeziku, odnosno u drugim nazivljima, čime su rezultati u glavnim zaključcima sukladni rezultatima istraživanja autorica Mihaljević i Ramadanović (2006) te Štambuk (2005). Tako se i u nazivlju arhitekture i urbanizma sufiksalna tvorba potvrđuje kao osobito plodna. 
No, nađene su i specifične razlike u nazivlju arhitekture i urbanizma. Tako, primjerice, korpus sadržava brojne nazive prefigirane prijedlozima (čak i u okviru sufiksacije), što nikako nije slučajno, već je u skladu sa suvremenim kognitivnolingvističkim pristupima semantici prijedloga, koji u njima vide ishodišnu domenu za označavanje prostornih odnosa kao jedne od temeljnih konceptualnih domena čovjekova iskustva i doživljaja svijeta. Prijedlozi tako svojim značenjima postaju predodžbene sheme u općem jeziku za razvoj svih ostalih značenja koja izražavaju apstraktne odnose. Budući da su arhitektura i urbanizam prototipne kognitivne domene za konceptualizaciju prostora i prostornih odnosa, brojni prijedlozi u funkciji prefiksa pritom funkcioniraju upravo u svojim prototipnim značenjima i sudjeluju u tvorbi novih tvorenica za označavanje pojmova u struci.

Druga nađena i važna specifičnost odnosi se na činjenicu da plodnost tvorbenoga načina nije u korelaciji s konvencionaliziranošću i učestalošću brojnih naziva u upotrebi. Naime, načini koji su u literaturi opisani kao slabije plodni (npr. slaganje i složeno-sufiksalna tvorba) u nazivlju arhitekture i urbanizma tvore visokofrekventne i udomaćene nazive, što možda i nije slučaj u drugim nazivljima. Možemo reći da su to čak i prilično plodni načini u tvorbi tipičnih i prepoznatljivih naziva u nazivlju arhitekture i urbanizma. To se osobito odnosi na složeno-sufiksalnu tvorbu.

Uključivanje semantičkoga aspekta $u$ analizu potvrdilo je temeljnu tezu suvremene jezikoslovne znanosti o nedjeljivosti i uzajamnoj ovisnosti gramatičkih i semantičkih struktura. Nazivlje u ovoj analizi pokazuje svoju kognitivnu dimenziju na više načina: ponajprije u potrebi uvažavanja specifičnoga kognitivnog makrokonteksta unutar kojega se naziv ostvaruje i koji je primarno odgovoran za njegovu ispravnu interpretaciju. Makrokontekst također bitno utječe na određene morfološke obrasce mijenjajući značenja novotvorenica ili pak generirajući ili reducirajući tvorbenu višeznačnost. Analiza je također ukazala na usku povezanost kognitivnoga makrokonteksta i načela kompozicionalnosti značenja koja se očituje ne samo pri stvaranju višerječnih naziva već i pri tvorbenim načinima koji generiraju složene ili izvedene tvorenice. Pri tome je značenje cjeline uvijek specifičnije od individualnih značenja njezinih sastavnica i za njegovu ispravnu interpretaciju nužno je poznavati kognitivni makrokontekst uporabe određenoga naziva. 
Vjerujemo da provedena analiza može biti od teorijske i praktične koristi za buduće analize načina kojima hrvatski jezik sudjeluje u izgradnji nazivlja drugih struka te u naporima oko njihove normizacije.

\section{Izvori za korpus:}

ARHITEKTURA, ORIS, ČIP i PROSTOR (stručni i znanstveni časopisi)

\section{Literatura:}

Anić, VladimiR. 1991. Rječnik hrvatskoga jezika. Novi Liber. Zagreb.

ANIČIĆ, DRAŽEn. 2002. Primjedbe na nazivlje iz područja građevinarstva u Rječniku hrvatskoga jezika Leksikografskog zavoda „Miroslav Krleža” i Školske knjige, Zagreb 2000. Građevinar 54/6. 379-394.

BABIĆ, StJEPAn. 1991. Tvorba riječi u hrvatskom književnom jeziku. Hrvatska akademija znanosti i umjetnosti. Zagreb.

BARIĆ, EugeniJa i dr. 1997. Hrvatska gramatika. Školska knjiga. Zagreb.

BARIĆ, EugEnIJA. 1980. Imeničke složenice neprefiksalne i nesufiksalne tvorbe. Liber. Zagreb.

BORIĆ, NEDA. 2011. Analiza leksičkih skupova u stručnom diskursu arhitekture u hrvatskom i engleskom jeziku. Doktorski rad. Filozofski fakultet Sveučilišta u Zagrebu. Zagreb. 339 str.

Horvat, Marijana; Ramadanović, Ermina. 2012. O složenicama i sraslicama (na primjerima iz Voltićeva Ričoslovnika). Filologija 58. 133-161.

KereKović, SnJeŽAna. 2012. Višerječni nazivi u tehničkome engleskom jeziku i njihove prijevodne istovrijednice u hrvatskome jeziku. Doktorski rad. Filozofski fakultet Sveučilišta u Zagrebu. Zagreb. 435 str.

Kuna, BRAnKo. 2006. Nazivlje u tvorbi riječi. Filologija 46/47. 165-181.

Langacker, Ronald W. 1987. Foundations of Cognitive Grammar. Vol I. Stanford University Press. Stanford, California.

Marković, Ivan. 2013. Uvod u jezičnu morfologiju. Disput. Zagreb.

Matovac, Darko. 2013. Semantika hrvatskih prijedloga. Doktorski rad. Filozofski fakultet Sveučilišta Josipa Jurja Strossmayera. Osijek. 311 str.

Matovac, Darko. 2014. Kognitivnolingvistički pristup poučavanju prijedloga. Lahor 9/1. 5-32. 
Mihaljević, Milica; Ramadanović, Ermina. 2006. Razradba tvorbenih načina u nazivlju. Rasprave Instituta za hrvatski jezik i jezikoslovlje 32. 193-211.

Raffaelli, IdA. 2009. Značenje kroz vrijeme. Poglavlja iz dijakronijske semantike. Disput. Zagreb.

Raffaelli, IdA. 2013. The Model of Morphosemantic Patterns in the Description of Lexical Architecture. Lingue e linguaggio 1. 47-72. doi.org/10.1418/73676.

ŠTAmbuK, AnušKa. 2005. Jezik struke i spoznaja. Književni krug. Split.

Tafra, Branka; Košutar, Petra. 2009. Rječotvorni modeli u hrvatskom jeziku. Suvremena lingvistika 67. 87-107.

\section{The Analysis of Word Formation Types in Croatian Architecture and Urban Planning Terminology with Special Emphasis on Semantics}

\section{Abstract}

This corpus-based research focuses on the analysis of word-formation types in Croatian architecture and urban planning terminology. The most common processes of term formation are identified and described with special emphasis on some unique features that characterize architecture terminology. The analysis also provides valuable insight into semantic aspects involved in these processes proving that morphological and semantic patterns in the formation of terms are closely intertwined and that they are inextricably linked with the specific cognitive macrocontext (the domain of use).

Ključne riječi: tvorbeni načini, nazivlje arhitekture i urbanizma, kognitivni makrokontekst, kompozicionalnost, morfološko-semantički obrasci

Keywords: word formation types, architecture and urban-planning terminology, cognitive macrocontext, compositionality, morpho-semantic patterns 